ISSN 2413-0877 Volume 1 (2015)

The 1st International Symposium on Aquatic Product Processing 2013

\title{
IMPACT OF FISH AGGREGATING DEVICE ON SUSTAINABLE CAPTURE FISHERIES
}

\author{
Roza Yusfiandayani*), Mulyono S. Baskoro, Daniel Monintja \\ Department of Fisheries Resources Utilization, Bogor Agricultural University \\ *e-mail : ocha_roza@yahoo.com
}

\begin{abstract}
The use of rumpon, a type of Fish Aggregating Device (FAD), has been traditional in Indonesia, particularly in eastern Indonesia waters since time immemorial (Reuter 1938; Nasution et al. 1986; Monintia 1976). The traditional tuna fishermen in Mamuju waters in the Province of South Celebes have used rumpons for a long time, although there is no record when the device was first used (Nasution et al. 1986). Any structure designed or made to attract free schooling fishes: rumpon (Indonesia), tendak (West Java), uncang (Sumatera), rompong (Sulawesi), payaos (Philippines). Local fishermen claimed that they learned how to construct the rumpon from their ancestors, but did not apply the device extensively until 1985 because of the low profitability of catching the swift swimming fishes. The use of rumpon for fishing activities has improved the effectiveness and efficiency of several fishing gear. However, the fast growing of rumpon utilization has raised a great concern on the sustainability of the fish resources. The rumpon management for responsible fisheries should consider the aspects of biology, location, environment, fishing gear, social and economic. The existing condition of rumpon has not fully understood and its usage in a responsible manner further elaboration also needed. For that purpose, the information of the past and present situation of rumpon in Indonesia will be important for further management. The main data were collected and compiled from various references, annual report of the Directorate General of Fisheries and research report of Central Research Institute for Fisheries. Additional data were made available from local fisheries agencies or related institutions. Structure of the rumpon installed in the Provinces of North Sumatera, West Sumatra, Lampung, West Java, East Java, North Celebes, Central Celebes, South Celebes, maluku and Papua are given in detail. There are 2 types of rumpon: the deep sea rumpon and shallow water rumpon. The differences among the rumpons in those areas are mostly found in material of mooring line, shape and material of float and structure of the attracting components. The mooring line is mostly made of polyethylene of $12-25 \mathrm{~mm}$ in diameter or nylon of 5-10 mm in diameter. There are wide variations of shape of floats. Generally they are divide into pontoon type or box shape made of steel and raft type made of bamboos. Attractors are made of coconut leaves, nipah leaves and pinag leaves. Some attractors are attached to the mooring line and the others are hung down from the float. They are operated in wide range of water depth from 20 to $1500 \mathrm{~m}$. The fishing ground conditions, bottom topography and bottom configuration are among the factors considered for the rumpon design and construction. The differences in construction are mainly due to the rumpon location, target species in each area and the fishing gear applied.
\end{abstract}

Keywords : fish aggregating device, rumpon, sustainable fisheries, Indonesia

\section{INTRODUCTION}

The use of rumpon, a type of Fish Aggregating Device (FAD), has been traditional in Indonesia, particularly in eastern Indonesia waters since time immemorial (Reuter 1938; Nasution et al. 1986; Monintia 1976). The traditional tuna fishermen in Mamuju waters in the Province of South Celebes have used rumpons for a long time, although there is no record when the device was first used (Nasution et al. 1986). Any structure designed or made to 
attract free schooling fishes: rumpon (Indonesia), tendak (West Java), uncang (Sumatera), rompong (Sulawesi), payaos (Philippines). Local fishermen claimed that they learned how to construct the rumpon from their ancestors, but did not apply the device extensively until 1985 because of the low profitability of catching the swift swimming fishes.

Some pelagic fishes have habit to be easily attracted and gather around floating object in the open ocean (Gooding and Magnuson 1967). Inove et al. (1968) noted that tunas and skipjack frequently accompany a drift wood in accompany the ocean. However, Scott (1969) observed that the associated schools of tuna could be divided into two groups. First, those affiliated with other animals, such as with porpoises, whales, sharks and the second one is those associated with inanimate objects, such as floating object, log, flotsam etc. Therefore, fishermen usually take advantage of these behaviors for fishing pelagic fishes.

Those knowledges are used as a basis of the usage of FAD for pelagic fishery enhancement. Several researchers have interested in studying the association of pelagic fish with floating object in the sea. Greenblatt (1979) and Inove et al. (1968) observed the association of tunas and skipjack with flotsam and drift wood in the Pacific Ocean. Hunter and Mitchell (1968) evaluated the different surface FADs configuration in the attraction of pelagic fish. Study of midwater FADs for attracting commercially and recreationally pelagic fishes has also been studied (Wickham et al. 1973; Wickman and Russell 1974). Firstly, FADs was commonly used in the coastal water areas with water depth of less than a hundred meters and for attracting small pelagic fishes. However, in the recent years these devices were deployed in the open ocean with water depth of more than a thousand meters and not only due to small pelagic fishes but also larger pelagic fishes such as tuna, dolphin fish, skipjack and marlins.

The intensive study on deep sea rumpon for skipjack tuna fisheries in Indonesia was started in 1976. The Marine Fisheries Research Institute conducted the field experiments and fishing industrial sector since 1980 and the commercial operations was successful in 1985. Rumpon affect skipjack and yellowfin catchability and abundance. They may also make the stocks more susceptible to overfishing (Mathews and Monintja 1996). Effects of rumpon on tuna fishing must be taken into account when addressing some of the concerns being raised about the coastal and offshore tuna fisheries in the Sulawesi Sea and elsewhere in Indonesian waters.

In Indonesia, fishers are using floating materials to aggregate pelagic species inclusive of tuna, mackerel, scads, sardines, etc. The man made floating devices are called rumpon, and widely employed by artisanal fishermen in the northern Java Sea and southern Celebes Sea. Rumpons used in those two areas, however, are quite different. Fishermen in Java construct their rumpon by coconut leaves and bamboo stems to catch small pelagic fishes, while the FAD used in southern Celebes Sea aimed at tuna and related fishes, and was originally made of bamboo raft with rattan mooring line. The traditional rumpon usually lasts only in short period of time of two month or less. 
The fast growing of rumpon utilization has raised a great concern on the sustainability of the fish resources. The rumpon management for responsible fisheries should consider the aspects of biology, location, environment, fishing gear, social and economic. The existing condition of rumpon has not fully understood and its usage in a responsible manner further elaboration also needed. For that purpose, the information of the present situation and the impact of rumpon in Indonesia will be important for further development in the near future.

\section{METHODS}

Data and information were collected and compiled from various references, international proceedings, reports of the Ministry of Marine Affairs and Fishery, Marine Fisheries Research Center, local fisheries agencies and related institutions.

\section{RESULT AND DISCUSSION}

There are two types of FADs or rumpon in Indonesia: the deep sea rumpon and shallow water rumpon. The deep sea rumpon for tuna have been utilized in tuna fishing ground over the waters in eight provinces inclusive of North Sumatra, West Sumatra, Lampung, West Java, East Java, North Celebes, Central Celebes, South Celebes, Maluku and Papua (Monintja 1993). The shallow water rumpon have been utilized in Lampung and Banten (Yusfiandayani 2004).

Table 1 Material and size of deep sea rumpon in Mamuju

\begin{tabular}{|c|c|c|c|c|}
\hline No. & Component & Material & Size & Amount \\
\hline \multirow[t]{6}{*}{1.} & Tuna rumpon buoy & & & \\
\hline & - Raft & Bamboo & $\mathrm{L}=11 \mathrm{~m}$ & $80-120$ bar \\
\hline & - Wooden bar & Wooden bar & $D=1.6-2.6 \mathrm{~m}$ & - \\
\hline & - Pajala/romping & & $\mathrm{L}=12 \mathrm{~m}, \mathrm{D}=8 \mathrm{~cm}$ & - \\
\hline & $\begin{array}{l}\text { - Main and } \\
\text { addition }\end{array}$ & Bamboo & $\mathrm{L}=9 \mathrm{~m}$ & $80-100$ bar \\
\hline & - Raft & & $B=1.6-1.8 m$ & - \\
\hline \multirow[t]{4}{*}{2.} & Attractor & & & \\
\hline & - Appendages & Coconut leaves & & $20-30$ sheet \\
\hline & - Rope & Polyethylene & $\Phi=4-6 \mathrm{~mm}$ & - \\
\hline & - Pajala & & $\mathrm{L}=30-50 \mathrm{~m}$ & - \\
\hline \multirow[t]{2}{*}{3.} & Mooring line pajala & & $\Phi=14-16 \mathrm{~mm}$ & $4-10$ coil \\
\hline & & & $\Phi=8-10 \mathrm{~m}$ & 5,000 bar \\
\hline 4. & Sinker & Stone & & $60-70$ piece \\
\hline
\end{tabular}




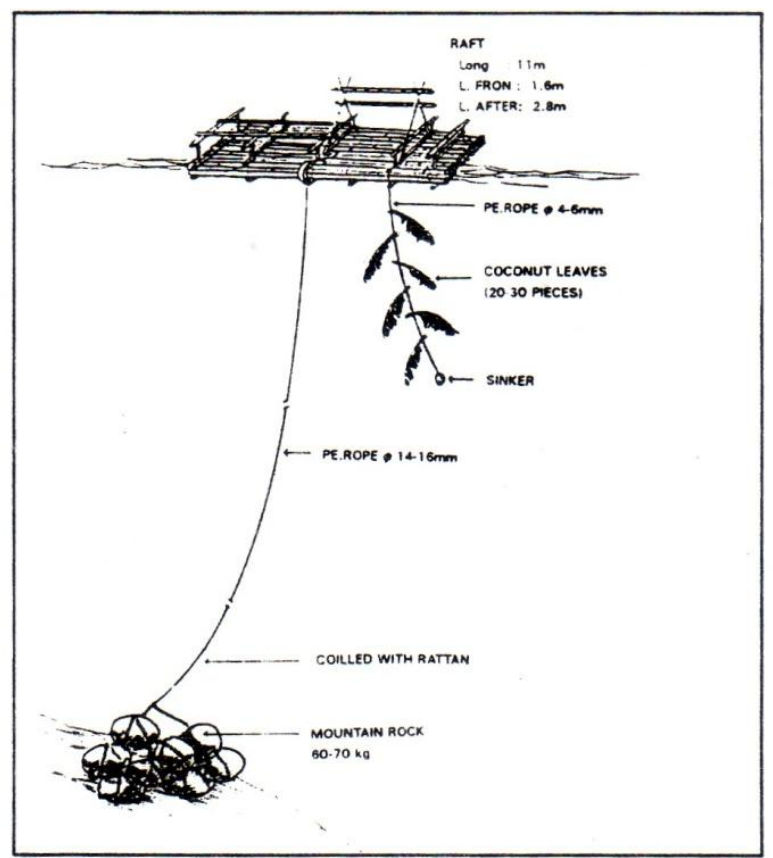

Figure 1. Deep sea rumpon in Mamuju (South Celebes Province Fisheries Agency 1987)

As similar to the FAD's utilized in other countries, the construction of rumpon in Indonesia basically consists of four main components, namely the buoy or float, the attractor, the mooring line and the sinker. The detail structure of the deep sea rumpon in Gorontalo can be shown at Figure 1. The Mamuju type of rumpon used in the Province of South Celebes is composed of bamboo raft as float, coconut leaves as the attractor (Table 1). The mooring line is composed by rattan string combined with polyethylene ropes. Fishermen are using mountain stones fixed by rattan string at the end of mooring line as the sinker (Figure 1). The Central Celebes type of rumpon is composed of bamboo raft as float and a pontoon as the attractor (Table 2). The sinker comprises of two oil drums (filled with concrete cement) and an anchor. Rattan webbing is installed to protect the PE rope from abrasion (Figure 2).

Table 2. Material and size of deep sea rumpon in Gorontalo

\begin{tabular}{|c|c|c|c|c|}
\hline No. & Component & Material & Size & Amount \\
\hline \multirow[t]{3}{*}{1.} & \multicolumn{4}{|l|}{ Buoy } \\
\hline & - Raft & Bamboo & $\Phi=16 \mathrm{~m}$ & 16 bar \\
\hline & - Pontoon & Wooden bar & $\begin{array}{l}D=0.3 \mathrm{~m}, \mathrm{~L}= \\
3 \mathrm{~m}, \mathrm{~B}=0.3 \mathrm{~cm}\end{array}$ & - \\
\hline 2. & Appendages & Coconut leaves & - & - \\
\hline \multirow[t]{3}{*}{3.} & \multicolumn{4}{|l|}{ Mooring line } \\
\hline & Rope & Polyethylene & $\Phi=4-6 \mathrm{~mm}$ & 6 coil \\
\hline & - Swivel & & $\Phi=5 / 8$ inch & $1 \mathrm{pc}$ \\
\hline \multirow[t]{3}{*}{4.} & \multicolumn{4}{|l|}{ Bottom sinker } \\
\hline & - $\quad$ Sinker & Concrete cement + iron bar & - & 2 units \\
\hline & - Anchor & Iron & - & 1 unit \\
\hline
\end{tabular}




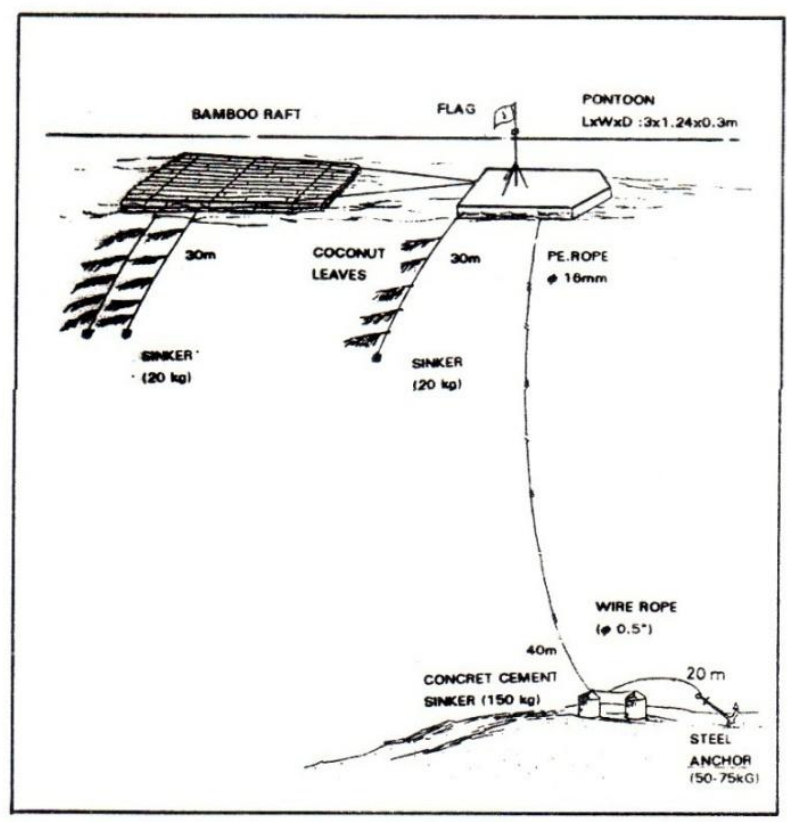

Figure 2. Deep sea rumpon in Gorontalo (Gorontalo Municipality Fisheries Agency 1990)

Up to 1987 a total number of 11 units of rumpon had been put into trial in West Sumatra waters. The first three units were designed under the Marine Fisheries Research, while the rest of eight units were designed and deployed by PT. Usaha Mina. The details of components are presented in Table 3. The rumpons deployed in the Gulf of Pelabuhan Ratu, West Java, have the structure of two layers raft type float and additional buoy of oil drum filled with polyethylene. The mooring line construction is similar to the PT. Usaha Mina type, with a minor modification in the material and sizes of the components (Table 4). Figure 3 showed the structure of deep sea rumpon in West Java.

Table 3. Material and size of deep sea rumpon in West Sumatra

\begin{tabular}{|c|c|c|c|c|}
\hline No. & Component & Material & Size & Amount \\
\hline \multirow[t]{2}{*}{1.} & Buoy & Bamboo & $\Phi=16 \mathrm{~m}, \mathrm{~L}=9 \mathrm{~m}$ & 38 bar \\
\hline & & Fibre glass & $\Phi=1 \mathrm{~m}, \mathrm{D}=6 \mathrm{~m}$ & 1 unit \\
\hline 2. & Attractor & Coconut leaves & - & 225 sheet \\
\hline \multirow[t]{4}{*}{3.} & Mooring line & Wire rope & $\Phi=16 \mathrm{~mm}, \mathrm{~L}=6 \mathrm{~m}$ & - \\
\hline & & Polyethylene & $\begin{array}{l}\Phi=18 \mathrm{~mm}, \mathrm{~L}=50 \\
\mathrm{~m}\end{array}$ & - \\
\hline & & Wire rope & $\underset{\mathrm{m}}{\Phi}=16 \mathrm{~mm}, \mathrm{~L}=30$ & - \\
\hline & & Polyethylene & $\Phi=22 \mathrm{~mm}$ & - \\
\hline \multirow[t]{2}{*}{4.} & Bottom sinker & $\begin{array}{l}\text { Concrete cement }+ \\
\text { iron bar }\end{array}$ & 200 It of drum oil & 1 unit \\
\hline & & Mountain's stone & $6-8 \mathrm{~kg} / \mathrm{pc}$ & 200 pc \\
\hline
\end{tabular}

Source : Padang Municipality Fisheries Agency 1988 


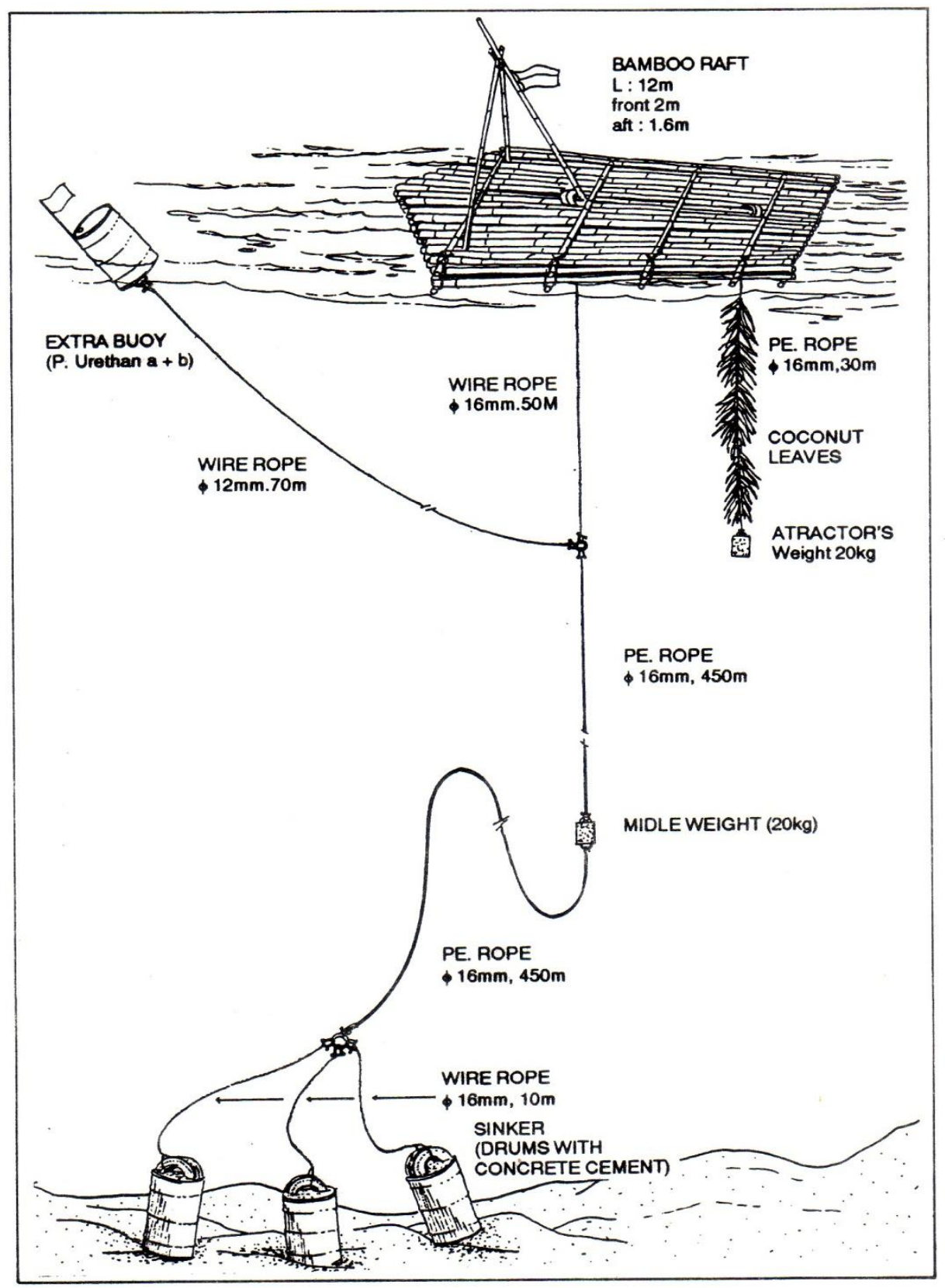

Figure 3 Structure of deep sea rumpon in West Java (Monintja et al. 1991) 
Table 4 Material and size of deep sea rumpon in West Java

\begin{tabular}{|c|c|c|c|c|}
\hline No. & Component & Material & Size & Unit \\
\hline \multirow[t]{3}{*}{1.} & Buoy & & & \\
\hline & - Raft buoy & Bamboo & $7 \mathrm{~m} \times(2 \mathrm{~m} ; 6 \mathrm{~m})$ & 1 \\
\hline & - Extra buoy & Oil drum & $200 \mathrm{lt}$ & 1 \\
\hline \multirow[t]{8}{*}{2.} & Attractor & & & \\
\hline & - Main attractor & Coconut leaves & 33.5 & 17 \\
\hline & - Ting rope & Nylon & $16 \mathrm{~mm} \times 30 \mathrm{~cm}$ & 1 \\
\hline & - Weight & Cement concrete & $20 \times 20 \times 22 \mathrm{~cm}$ & 1 \\
\hline & - Shackle & Steel & $18 \mathrm{~mm}$ & 1 \\
\hline & - Thimble & Steel & $16 \mathrm{~mm}$ & 2 \\
\hline & - Snap & Steel & $10 \mathrm{~mm}$ & 1 \\
\hline & - Ring & Steel & $16 \mathrm{~mm}$ & 1 \\
\hline \multirow[t]{10}{*}{3.} & Mooring line & & & \\
\hline & - Wire rope & Steel & $16 \mathrm{~mm} \times 80 \mathrm{~m}$ & 1 \\
\hline & - Line & PE & - & 1 \\
\hline & - Shackle & Steel & $18 \mathrm{~mm}$ & 16 \\
\hline & - Swivel & Steel & $16 \mathrm{~mm}$ & 4 \\
\hline & - Thimble & Steel & $16 \mathrm{~mm}$ & 12 \\
\hline & - Ring & Steel & $24 \mathrm{~mm}$ & 2 \\
\hline & - Counter weight & Cement concrete & $20 \times 20 \times 22 \mathrm{~cm}$ & 1 \\
\hline & - Ring & Steel & $16 \mathrm{~mm}$ & 4 \\
\hline & - Chain & Steel & $8 \mathrm{~mm}$ & 4 \\
\hline \multirow[t]{5}{*}{4.} & Extra line & & & \\
\hline & - Wire rope & Steel & $12 \mathrm{~mm} \times 7 \mathrm{~cm}$ & 1 \\
\hline & - Shackle & Steel & $16 \mathrm{~mm}$ & 1 \\
\hline & & & $18 \mathrm{~mm}$ & 1 \\
\hline & - Clamps & Steel & $12 \mathrm{~mm}$ & 6 \\
\hline 5. & Sinker & $\begin{array}{l}\text { Oil drums filled } \\
\text { with concrete } \\
\text { cement }\end{array}$ & $200 \mathrm{~kg}$ & 3 \\
\hline
\end{tabular}

Source : Monintja et al. 1991

The Banten type of rumpon in Sunda Strait as shallow water rumpon, have the same material of the components of deep sea rumpon (Table 5). The Lampung types in Teluk Belebuh Bay have the same component with the Banten rumpon. The depth of the shallow water rumpon is $20 \mathrm{~m}$ (figure 4).

Table 5. Material and size of shallow water rumpon in Banten

\begin{tabular}{cllcc}
\hline No. & Component & \multicolumn{1}{c}{ Material } & \multicolumn{1}{c}{ Size } & Amount \\
\hline 1. & Buoy & & & \\
& $-\quad$ Raft & Bamboo & $\Phi=0.1 \mathrm{~m}, \mathrm{~L}=15 \mathrm{~m}$ & $3-6$ bar \\
2. & Attractor & Coconut leaves & - & 25 sheet \\
3. & Mooring line & Polyethylene & $\Phi=18 \mathrm{~mm}, \mathrm{~L}=63 \mathrm{~m}$ & - \\
4. & Bottom sinker & Mountain's stone & $50 \mathrm{~kg} / \mathrm{pc}$ & $2 \mathrm{pc}$ \\
\hline
\end{tabular}

The use of deep sea FAD in the Indonesia waters must be have license from the Directorate of Capture Fisheries, Ministry of Marine Affairs and Fisheries Republic of Indonesia. Licensing process for deep sea FAD in Indonesia waters is to send document consists of design and construction deep sea FAD, rumpon ownership, location of placement deep sea 
FAD to Directorate of Capture Fisheries, Ministry of Marine Affairs and Fisheries Republic of Indonesia. The documents will be studied and proposed in the survey. After studied and surveyed the license will be given to the owner deep sea FAD.

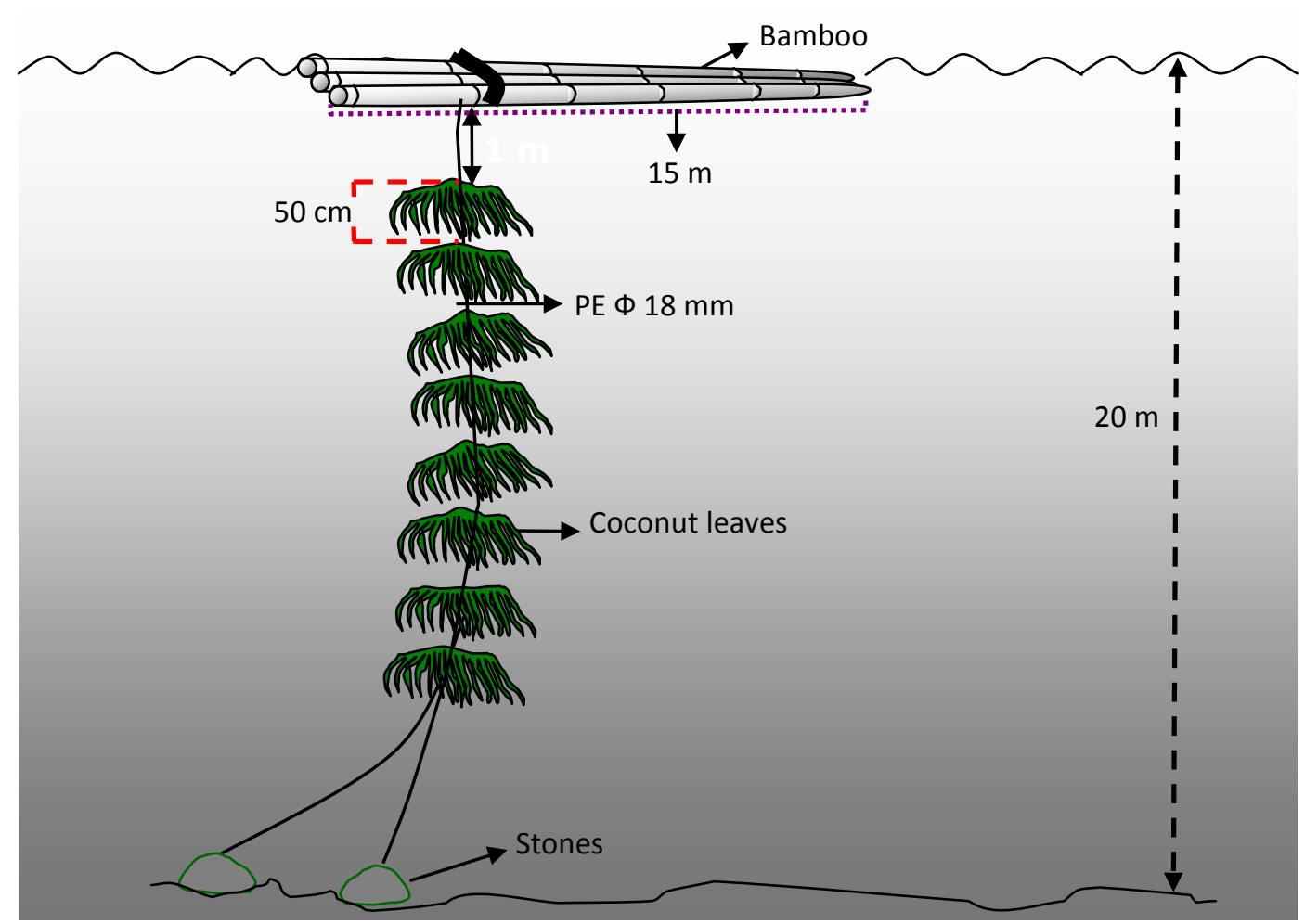

Figure 4. Structure of shallow water rumpon in Banten (Yusfiandayani 2004)

Number of licensed deep sea and shallow water rumpon in Indonesia for the period of 2006-2008 is shown in Figure 5. The highest are 41 units in South Celebes and the lowest in Ceram Sea with 4 units. The comparison number of deep sea and shallow water rumpon in Indonesia can be shown in Figure 6. The numbers of deep sea rumpon are 54 units, and the shallow water rumpon are 39 units.

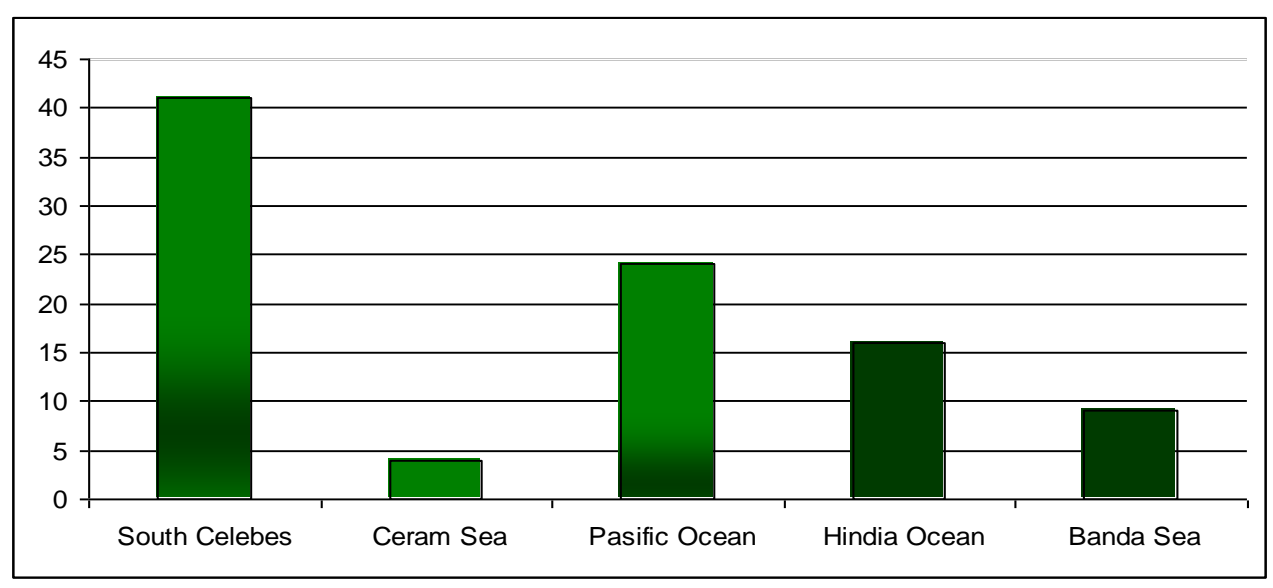

Figure 5. Number of deep sea and shallow water rumpon in Indonesia 


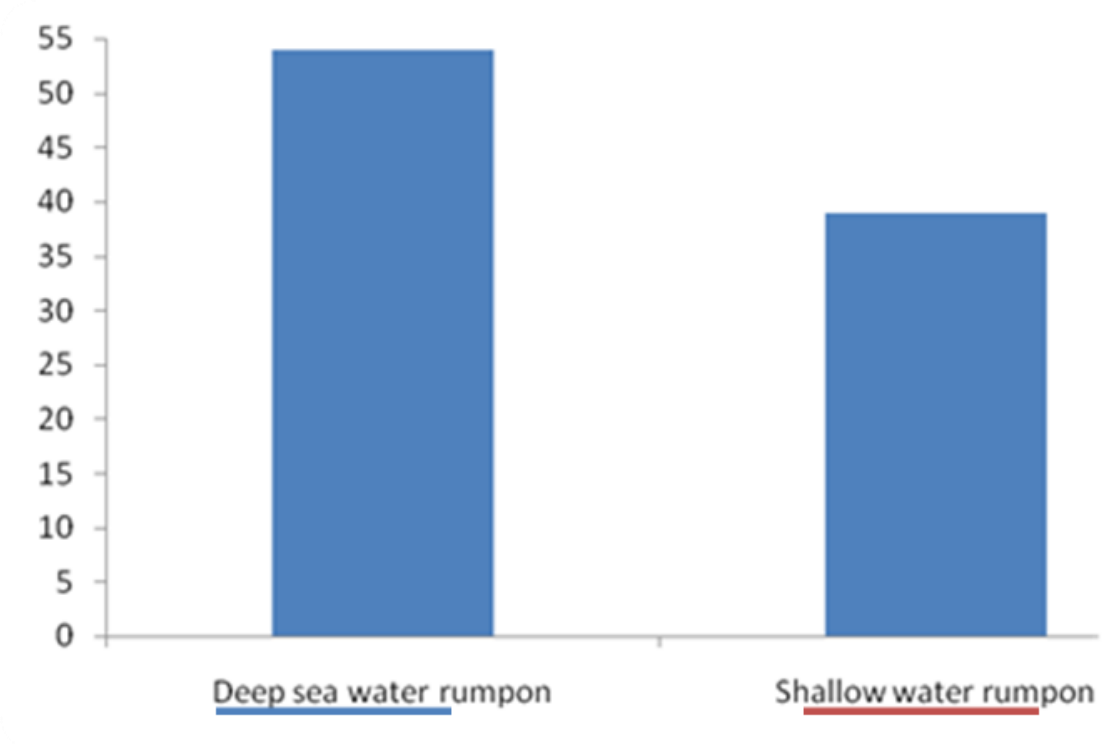

Figure 6. Number of licensed deep sea and shallow water rumpon in Indonesia

Several research conducted on the impact of FAD on the fisheries showed positive results :

1) In Indonesia (Monintia and Mathews 2000)

Eastern Indonesia skipijack fisheries, pole and line

Increased in CPUE $41 \%$

Landing's of fish per ton of live bait increased 24\%

Reducing diesel oil consumption : $46 \%$

Increasing profit: 10 to 60 million rupiah per boat

Increasing cacthability $40 \%$

2) In Pacific Ocean (Sakagawa GT 2000)

Rate of success fishing $96 \%$

High yield rate (37 ton/set)

FAD improved the fleet performance

3) In Solomon Island (Sibiospere 2000)

The FAD Utilization has increased the total yield of skipjack tuna in Solomon Islands

Saving in operational cost

Reducing fishing searching time

Better regularity of landings

4) In CapeVerde (Helene Rey-Valette, Pericles Martin 2000)

D The FAD has stabilized the fishing activies in Cape Verde Islands

5) In Central Western Pacific Ocean (Coan and Bartoo 2000)

FAD catches increased from $2000 \mathrm{mt}$ (1995) to $64000 \mathrm{mt}$ (1996)

FAD catch per set remained high

Bigeye tuna catches increased 3 fold 
6) In Malaysia (Rumpet 2000)

FAD has proven to enhance the catch of pelagic fish

Negative impact of FAD on the fisheries were also reported:

1) In Indonesia (Mathews, Monintia, Naamin 1996)

The develepment of industrial tuna purse seiners equipped with FAD from Philippnes had caused decline in CPUE, of the Tomini Gulf fisheries.

2) In Indonesia (Naamin, Mathews, Monintja 1996)

> The introduction of Philippine rumpon into Indonesia EEZ- and teritorial waters has reduced the CPUE of the local skipjack fisheries to $23 \%$.

The CPUE of yellowfin tuna in Manado and Bitung declined after the introduction of rumpon in 1990.

3) Wordwide review (Fonteneau, Pallares, Pianet 2000)

D The use of FADs needs to be controlled and limited to sustainable biological levels.

4) In Indonesia (Yusfiandayani 2004)

Most of the small pelagic fish (72\%) caught around FAD in Pasauran waters are immature fish.

$>$ The number of FAD in Pasauran waters with area $115,4 \mathrm{~km}^{2}$ are 4 units.

The each of FAD area $23 \mathrm{~km}^{2}$ or 3 miles.

International issues on the impact of FAD have been brought up since 1999 in the International Symposium on Tuna Fisheries and Fish Aggregating Device in Martinique, France. The issues includes the fastly growing of FAD utilization in the Eastern Pasific Ocean, as the drifting aggregating devices, were reported catching the small size and immature fishes. Pro and con on FAD application on purse seine fishing goes on and on, since the gear is categorized as non selective fishing gear. In Indonesia, several policies and management measures have been officially assigned by the government, such as the ministry's regulation No. $51 / \mathrm{Kpts} / \mathrm{IK} .250 / 1 / 97$ and ministry's regulation No.30/Men/2004 on the Rumpon Deployment and Utilization, and the Decision of Director General of Capture Fisheries No. 4179/DPT.2/PI.340.D2/IX/08 on the prohibition of using rubber type for rumpon. The ministry regulation discussed about FAD deployment zones, FAD deployment licensing, FAD marking and $F A D$ operation reporting.

Hilborn and Medley (1989) proposed the model for the analysis of fishing tuna from FAD. The model are described for determining the optimum number of FAD's to be deployed and the optimum number of vessels in a fishery. Hilborn and Medley reported that the number of FAD's for a single tuna purse seine vessel operating in 10,000 $\mathrm{km}^{2}$. Profits are maximized with about 40 FAD's, which corresponds to one FAD every $250 \mathrm{~km}^{2}$, or mean distance between FAD's of a $5.8 \mathrm{~km}$. Several researchers have interested in studying the interaction between tuna or small pelagic fishes with FAD's in the sea with the Hilborn and Medley model (1989). 
Widodo et al. (1993) observed that the number of rumpon in Maluku waters are catch and profit depend upon the number of FAD's for a single vessel pole and line operating in 7,769 $\mathrm{km}^{2}$. The profits are optimized with about 40 FAD's, which corresponds to one FAD every 200 $\mathrm{km}^{2}$, or mean distance between FAD's of $14 \mathrm{~km}$ (about 7.6 nautical miles). Luasunaung (1999) showed that the number of rumpon in Tomini Teluk, South Sulawesi waters are catch and profit depend upon the number of FAD's for a single vessel soma pajeko operating in $695 \mathrm{~km}^{2}$. The profits are optimized with about 55 FAD's, which corresponds to one FAD every $13.7 \mathrm{~km}^{2}$, or mean distance between FAD's of 3.7 km (about 2 nautical miles). Yusfiandayani (2004) observed that the rumpon fisheries in Pasauran waters revealed that the optimum number of rumpon is 4 units, for the water area of $115.4 \mathrm{~km}^{2}$, and the mean distance of each rumpon is 5 $\mathrm{km}$ (about 3 nautical miles). The 4 units rumpon in Pasauran waters could render 154.4 ton of total catch/year with a profit of 38.2 million rupiah/year.

Species composition and size of fish aggregating around the rumpons are skipjack tuna, clupeids and carangids in the waters off Sorong and Bacan Island. Examination on skipjack caught around rumpon in Bacan waters showed four features : 1) the size of fish does not differ significantly; 2) amount of catch increased as the fishing operation approached the rumpon; 3) amount of catch decreased from a peak in the early morning toward afternoon and 4) occurrence of fish schools for efficient operation delayed with distance from rumpon. The fishing operated most actively between $07.00 \mathrm{AM}$ to $08.00 \mathrm{AM}$ in the zone within $500 \mathrm{~m}$ from rumpon, between $08.00 \mathrm{AM}$ to $09.00 \mathrm{AM}$ in the zone from $500 \mathrm{~m}$ to $1,000 \mathrm{~m}$, between $10.00 \mathrm{AM}$ to $11.00 \mathrm{AM}$ in the zone from $1,000 \mathrm{~m}$ to $5,000 \mathrm{~m}$ and between $13.00 \mathrm{PM}$ to 14.00 PM in the waters outside 5, $000 \mathrm{~m}$ from rumpon (Monintia 1993).

Yusfiandayani (2004) observed that Cocos nucifera leaves are the best attractor material based on the thickness of cuticle, thickness of epidermis, density of periphyton, and number of fish species in all seasons. Further, the Gonado Somato Index (GSI) of small pelagic fish were caught around rumpon are GSI I 4\%, GSI II 33\% and GSI III 35\%. This result indicated that the small pelagic fish caught around rumpons are 'immature fish' and could cause recruitment overfishing. The periphytons in the attractors were also found in the stomach content of 6 small pelagic species fish around rumpon. The rumpon fisheries in Pasauran have not met with the criteria of the Code of Conduct for Responsible Fisheries. The GSI of small pelagic fish were caught around rumpon indicated that the rumpon could cause recruitment overfishing. Rationalization of the existing 45 to 4 units rumpon in Pasauran waters is recommended to ensure the sustainability of the fisheries.

The Shimamaki study (Polovina and Sakai 1989) could not identify any biological impacts from the redistribution of exploitable biomass, but there were potentials impacts. Because the density of the exploitable biomass per-area of habitat had been reduced, growth and also natural mortality of the stock may have been impacted as well. However, the greatest impact may be a reduction in exploitable biomass if fishing at the artificial habitat is not restricted. The sitting of artificial habitat usually allows them to be more accessibility increases fishing 
effort and can result in higher fishing mortality. An increase in fishing mortality will decrease the exploitable biomass in the area exploited. Whether the decrease in exploitable biomass results in lower future catches or recruitment to the fishery either locally of in an adjacent region depends on the stock dynamics. If the stock is migratory, then heavy fishing mortality in one region will result in lower levels of exploitable biomass in adjacent regions. If there is a strong regional stock recruitment relationship, then heavy local fishing mortality could reduce future recruitment.

FAO technical guidelines for responsible fisheries (FAO 1996) pointed out that : fish aggregating tecnology should be futher developed to improve the performance of anchored and drifting devices; the management system concerning FADs should set out the responsibility of the competent authority and the users for minimum design standards, operation and maintenance of FADs; the competent authority should also establish a system of approval for the deployment of FADs and maintain a record of the owner; the competent authority should ensure that the authorization to fish at FADs includes details of the fishing methods to be used as well as a requirement for reporting catches, FADs whether drifting or anchored, should means to identify their position by day and by night and the component authority should also establish a system for the reporting of lost FADs and retrieval of those considered to be a danger to navigation.

Based on the above guidelines, a comprehensive management program is ought to be established for the FAD operation. Vision, mission, objectives, target and management strategies on FAD are needed to be formulated, covering : integrated processes, focusing the condition expected by the stakeholders, what to be achieved, how much to be produced, what action to be done, how to achieve, should be discussed together by the stakeholders (not only by the government). Issues to be solved concerning the FAD management could be : the lack of data and information; indication of over capacity and overfishing; decrease of fishing business performance; conflicts; habitat destructions; threats on biodiversity; IUU fishing; bycatch; discards; lack of law and regulations; law enforcement problems, etc. Management measures and detailed action to be applied, could include : FAD fishing ground zoning, fishing season, type and material of FAD to be allowed, number of FAD to be licensed, distance among FADs, number and type of fishing gear and method to be allowed, business management, socio and cultural consideration.

\section{CONCLUSION}

The conclusion of this papers are :

1. The FAD utilization has increased the effectiveness, efficiency and regularity of the fishing activities.

2. Unmanaged FAD fisheries will end up to overcapacity, overfishing and unsustainable fisheries.

3. The FAD fisheries has to be optimally managed to assure its sustainability through research, consultation, planning, resource allocation, and law enforcement. 


\section{REFERENCES}

Clark C. W., and Mangel M. 1979. Aggregation and fishery dynamics : a theoretical study of schooling and the purse seine tuna fisheries. Fish. Bull. $77: 317-337$.

Gooding R. M. and. Magnuson J. J. 1967. Ecological Significance of A drifting Object to Pelagic Fishes. Pasific Science, 21 : 486-497.

Gorontalo Municipality Fisheries Agency. 1990. Fisheries Annual Report. 1989. (In Indonesian). $40 \mathrm{p}$.

Greenblatt P. R. 1979. Associations of Tuna with Floatsams in The Eastern Tropical Pasific. Fishery Bulletin, 77 (1) : 147-155.

Hilborn R. and Medley P. 1989. Tuna Purse Seine Fishing with Fish Aggregating Devices (FADs) : Model of Tuna FADs Interaction. Canadian Journal Fish Aquatic. Sci. 46 : 28-32.

Hunter J. L. and Mitchell, C. T. 1968. Association of Fishes with Flotsam in the Offshore Waters of Central America. U. S. Fish. Wildl. Serv., Fishery Bulletin, 66: 13-29.

Hunter J. R. and. Mitchell C. T. 1968. Field Experiments on the Attraction of Pelagic Fish to Floating Objects. Journal Cons. Perm. Int. Exploration. Mer, 31 (3) 427 - 434.

Inove M., Amano R. Iwasaki, $Y$ and Yamauti M. 1968. Studies on environment alluring skipjack and other tunas II. On the driftwoods accompanied by skipjack and tunas. Bull. Japan Soc.Sci.Fish., 34 : 283-287.

Karl C. Samples and John T. Sproul. 1985. Fish Aggregating Devices and Open Access Commercial Fisheries : A Theoretical Inquiry. Bulletin of Marine Science, 37 (1) : 305 317.

Luasunaung A. 1999. Soma Pajeko Fisheries with Rumpon : The interaction between Decapterus macarellus and Rumpon in Molibagu waters, Tomini Bay. (In Indonesian, Eng. Abstract). Postgraduate School. Bogor Agricultural University, Bogor. (Unpublished).

Mathews C. P. and. Monintia D. R 1996. Assessment of the Role of foreign and Industrial Tuna Fishing in Indonesia's EEZ, Archipelagic and Territorial Waters. Report Central Research Institute For Fisheries Research, Jakarta.

Mathews C. P., Monintia D. R. and Naamin N. 1996. Studies of Indonesian Tuna Fisheries : Part 2. Changes in Yellowfin Abundance in The Gulf Of Tomini And North Sulawesi. In : Shomura, R. S., J. Majkowski and R. F. Horman (Eds.). Scientific Papers from the Second FAO Expert Consultation on Interactions of Pasific Tuna Fisheries, 23-31 January 1995, Shimizu, Japan. P. 298-305.

Monintia D. R. 1976. Modernizing the traditional rumpon to increase fishermen's income. (In Indonesia). Documented papers proposed to Directorate General of Fisheries, Jakarta. $6 \mathrm{p}$.

Monintja D. R., Baskoro M. S. and Purbayanto A. 1991. Design and construction of fish aggregation device for skipjack and tuna fishing in Southern Java waters. (In Indonesian, Eng. Abstract). Proceeding of National Seminar on Research of Department of Higher Education, Sawangan, Bogor. 21-24 January 1991. P. 395-409.

Monintja D. R. 1993. Study on the Development of Rumpon as Fish Aggregating Devices (FADs). Maritek, Bulletin ITK, FPIK-IPB. 3(2) : 137 p.

Monintia D. R., and Mathews C. P. 1999. The skipjack fishery in Eastern Indonesia : distinguishing the effects of increasing effort and deploying rumpon (FADs) on the stock. Scientific papers from the International Seminar on Fish Aggregating Device, 15-19 October 1999, Martinique, France. P. 435-448.

Nasution Ch., Merta G. S and Arifudin R. 1986. Study on romping and their aspects in Mamuju waters to develop tuna fishery in South Celebes. Journal of Marine Fisheries Research 37, p. 31-58.

Padang Municipality Fisheries Agency. 1988. Report on SFDP Project. (In Indonesian). 36 p.

Polovina J. J. and Sakai I. 1989. Impacts of artificial reefs on fishery production in Shimamaki, Japan. Bull. Mar. Sci. 44 : 997 - 1003.

Reuter J. 1938. Voorlopig mededeling omtrent het roempoen onderzoek. Mededeling no. 2 B. Institut voor Zeevisscherij. Batavia. 4 p.

Scott J. M. 1969. Tuna schooling terminology. Calif. Fish. Game. 55 (2) : $136-140$.

South Celebes Fisheries Agency. 1987. Rompong in Mamuju District. (In Indonesian). 9 p.

Wickham A. D., Watson J. W. and Ogren LH. 1973. The efficiency of midwater artificial structures for attracting pelagic sport fish. Trans. Amer. Fish. Soc. $3: 563-572$.

Wickham A. D. and Russel G. M.1974. An evaluation of midwater artificial structures for attracting coastal pelagic fishes. Fish. Bull. 72 (1): 181-191. 
Widodo J., Bachtiar G. dan Merta I. G. S 1993. Interaksi antara Tuna dan Rumpon sebagai Alat Bantu Pengumpul Ikan pada Perikanan Huhate (Pole and Line) di Perairan Maluku dan Irian Jaya. Prosiding Simposium Perikanan Indonesia I, Jakarta. P. 353-359.

Yusfiandayani R. 2004. Study on the Aggregation Mechanism of Small Pelagic Fish around Rumpon and Its Fisheries of Development in Pasauran Waters, Province of Banten. (In Indonesian, Eng. Abstract). Postgraduate School. Bogor Agricultural University, Bogor. (Unpublished). 